\title{
Effects of different amino acid levels and a carvacrol-thymol blend on growth performance and intestinal health of weaned pigs
}

Yanan Wang ${ }^{1}$, Zhipeng Yang ${ }^{1}$, Yuanfei Zhou', Jiajian Tan², Haiqing Sun ${ }^{2}$, Defa Sun ${ }^{3}$, Yuyun Mu ${ }^{3}$, Jian Peng ${ }^{1,4}$ and Hongkui Wei ${ }^{1,4^{*}}$ (D)

\begin{abstract}
Background: Over the past years, antibiotic growth promoter had been restricted in animal husbandry production in many countries because of antimicrobial resistance and foodborne antibiotic residues. However, the problems of poor intestinal health and low growth efficiency of piglets have not been solved completely in an antibiotic-free diet, and it is urgent to explore alternatives to antimicrobial growth promoters.

Methods: Here, a total of 532 weaned pigs were assigned to one of 4 treatments, the low amino acid (AA) level diet ( 1 to $d 14$ is $1.35 \%$, $d 15$ to $d 42$ is $1.25 \%$ ) (Low AA), the low AA level diet supplementation with a carvacrolthymol blend (50 mg carvacrol and $50 \mathrm{mg}$ thymol/kg of diet) (CB) (Low AA+CB), the high AA level diet (d 1 to $\mathrm{d} 14$ is $1.50 \%, \mathrm{~d} 15$ to $\mathrm{d} 42$ is 1.40\%) (High AA), and the high AA level diet supplementation with a CB (High $A A+C B)$, respectively. Then we measured growth performance and intestinal health indicators of weaned pigs.

Results: Results showed that high AA level significantly reduced plasma urea nitrogen, plasma Interleukin-6 (IL-6) and fecal lipocalin-2 contents $(P<0.05)$, significantly increased the relative abundance of fecal Lactobacillus and Enterococcus, and had a trend to increase the fecal secretory immunoglobulin A (slgA) and mucin 2 (MUC 2) contents $(P<0.05)$ in piglets, thereby alleviating the diarrhea of piglets and reducing the feed conversion ratio (FCR) of piglets during d 1 14 after weaning. Dietary supplementation with $C B$ significantly increased the activity of plasma antioxidant enzymes T-SOD and GSH-px $(P<0.05)$, while significantly reduced plasma malondialdehyde (MDA), plasma interleukin-1 $\beta$ (IL-1 $\beta)$, plasma endotoxin and D-lactic acid contents $(P<0.05)$. Meanwhile, $C B$ significantly decreased fecal lipocalin-2 contents and the abundance of fecal Escherichia coli $(P<0.05)$. Thus, we hypothesis that dietary supplementation with CB significantly increased the average daily gain (ADG) of piglets $(P<$ 0.05) during d 1 14 after weaning through promoting intestinal health.
\end{abstract}

\footnotetext{
* Correspondence: weihongkui@mail.hzau.edu.cn

'Department of Animal Nutrition and Feed Science, College of Animal

Science and Technology, Huazhong Agricultural University, Wuhan 430070,

China

${ }^{4}$ The Cooperative Innovation Center for Sustainable Pig Production, Wuhan 430070, China

Full list of author information is available at the end of the article
}

(c) The Author(s). 2022 Open Access This article is licensed under a Creative Commons Attribution 4.0 International License, which permits use, sharing, adaptation, distribution and reproduction in any medium or format, as long as you give appropriate credit to the original author(s) and the source, provide a link to the Creative Commons licence, and indicate if changes were made. The images or other third party material in this article are included in the article's Creative Commons licence, unless indicated otherwise in a credit line to the material. If material is not included in the article's Creative Commons licence and your intended use is not permitted by statutory regulation or exceeds the permitted use, you will need to obtain permission directly from the copyright holder. To view a copy of this licence, visit http://creativecommons.org/licenses/by/4.0/. The Creative Commons Public Domain Dedication waiver (http://creativecommons.org/publicdomain/zero/1.0/) applies to the data made available in this article, unless otherwise stated in a credit line to the data. 
Conclusion: These results suggest that high AA level and dietary supplementation with CB improved the growth performance of weaned pigs in an antibiotic-free diet by improving AA metabolism and intestinal antioxidant capacity.

Keywords: Amino acids, Antioxidant capacity, Carvacrol and thymol, Intestinal health, Plant extracts, Weaned pigs

\section{Introduction}

Antibiotics are usually used to prevent and treat animal diseases which play an important role in animal husbandry production [1]. There are approximately $75 \%$ of antibiotics used in animal husbandry production worldwide since antibiotics were discovered to accelerate pig and chicken growth [2]. In recent years, many countries have realized that the abuse of antibiotic had led to antimicrobial resistance and foodborne antibiotic residues, and began to implement antibiotic free feeding [3]. Following the European Union and the United States, China began to ban antimicrobial growth promoters from July 1,2020 . However, the problems of poor intestinal health and low growth efficiency of weaned pigs have not been solved completely in an antibiotic-free diet [4]. Therefore, it is urgent to explore alternatives to antimicrobial growth promoters.

Dietary AA are metabolized in the small intestine, and about one third of the dietary essential AA are consumed through the first pass metabolism of the intestine $[5,6]$. Porcine small intestine bacteria can quickly utilize lysine, arginine, threonine, and glutamic acid [7, 8]. Slightly less than lethal doses of antibiotic could significantly reduce total bacterial abundance [9]. Thus, the increase in the abundance of microbes induced by antibiotic-free diet in the small intestine may lead to an increase in AA requirements. Moreover, the requirement of lysine or methionine as energy sources or to support the immune system may also be significantly higher than that in an antibiotic-free diet [10]. Hence, high AA level may be an effective measure to improve the growth performance of weaned pigs fed with antibiotic-free diet [10-12].

Carvacrol and thymol are both phenolic monoterpenoids, which are extracted form origanum vulgare. Carvacrol and thymol have been proven to exert a variety of physiological activities, such as anti-microbial, antiinflammatory, anti-oxidative, immune modulation, and improving intestinal morphology and intestinal mucosal integrity [13-16]. Thus, carvacrol and thymol are widely used as a substitute for antibiotics in animal diets [1618]. Our previous studies also found that dietary supplementation with $100 \mathrm{mg} / \mathrm{kg} \mathrm{CB}$ can alleviate intestinal oxidative stress, increase the abundance of beneficial bacteria, and decrease the abundance of harmful bacteria in weaned pigs [16].

Here, we hypothesized that high AA level and dietary supplementation with $\mathrm{CB}$ could effectively control the diarrhea of weaned pigs and improve the growth performance of weaned pigs. To test the hypothesis, we assigned 532 weaned pigs to 4 treatments (Low AA, Low AA + carvacrol-thymol blend, High AA, High AA + carvacrol-thymol blend) for $42 \mathrm{~d}$ after weaning respectively, and collected the plasma and fecal at $\mathrm{d} 7,14,42$ to test effects of different AA levels and a carvacrol-thymol blend on growth performance and intestinal health of weaned pigs.

\section{Methods \\ Animals and experimental design}

A total of 532 weaned pigs (Duroc $\times$ Large White $\times$ Landrace) with an initial BW of $7.74 \pm 1.23 \mathrm{~kg}$ were randomly allocated to 4 groups with four-five pens $(7.1 \mathrm{~m} \times$ $4.7 \mathrm{~m}$ ) per treatment and 28 weaned pigs per pen, the stocking density is $1.19 \mathrm{~m}^{2} / \mathrm{pig}$. Porcine circovirus (PCV), pseudorabies virus (PRV), classical swine fever (CSF), porcine reproductive and respiratory syndrome virus (PRRS) vaccine were injected at 3,18 and $22 \mathrm{~d}$ respectively. The experiment was designed with $2 \times 2$ factors including a low level AA diet (Low AA), a low level AA diet supplemented with carvacrol-thymol blend (50 $\mathrm{mg} / \mathrm{kg}$ carvacrol and $50 \mathrm{mg} / \mathrm{kg}$ thymol of diet) (Low $\mathrm{AA}+\mathrm{CB}$ ), a high level AA diet (High AA), a high level AA diet supplemented with carvacrol-thymol blend (50 $\mathrm{mg} / \mathrm{kg}$ carvacrol and $50 \mathrm{mg} / \mathrm{kg}$ thymol of diet) (High $\mathrm{AA}+\mathrm{CB}$ ) for $42 \mathrm{~d}$. The level of SID Lys of low AA group from $\mathrm{d} 1$ to $\mathrm{d} 14$ is $1.35 \%$, and then change to $1.25 \%$ from d 15 to d 42. The level of SID Lys of high AA group from $\mathrm{d} 1$ to $\mathrm{d} 14$ is $1.50 \%$, and then change to $1.40 \%$ from d 15 to $\mathrm{d} 42$. The carvacrol-thymol blend was provided by Novus International Inc. (St. Louis, MO, USA) as Next Enhance $150^{\circ}$ (1:1, Thymol:Carvacrol). According to the manufacturer, Next Enhance 150 contains $50 \%$ encapsulated active components (thymol and carvacrol) but no other nutrients. The composition and nutrient level of the basal diet are shown in Tables 1 and 2 . All of the piglets were given ad libitum access to water and feed.

\section{Determinations of growth performance and diarrhea}

The body weight (BW) of the pigs were recorded at $\mathrm{d} 1$, d 14 and d 42; Feed intake of weaned pigs was recorded every day, and average daily feed intake (ADFI), average daily gain (ADG), and FCR were calculated per pen. The diarrhea rate was recorded during d 1 14 after weaning, 
Table 1 Ingredients and nutrient composition of diet during 1 $\sim 14 \mathrm{~d}$

\begin{tabular}{|c|c|c|c|c|}
\hline \multirow[t]{2}{*}{ Composition, $\%$} & \multicolumn{2}{|l|}{ Low AA } & \multicolumn{2}{|l|}{ High AA } \\
\hline & $\mathrm{CB}(-)$ & $\mathrm{CB}(+)$ & $\overline{\mathrm{CB}(-)}$ & $\mathrm{CB}(+)$ \\
\hline Prepuffed raw materials & 53.08 & 53.03 & 54.16 & 54.11 \\
\hline Fermented soybean meal & 8.90 & 8.90 & 7.40 & 7.40 \\
\hline Yeast & 2.08 & 2.08 & 2.08 & 2.08 \\
\hline Fermented products & 6.67 & 6.67 & 6.67 & 6.67 \\
\hline Low protein whey powder & 12.50 & 12.50 & 12.50 & 12.50 \\
\hline High protein whey powder & 2.78 & 2.78 & 2.78 & 2.78 \\
\hline Glucose & 2.78 & 2.78 & 2.78 & 2.78 \\
\hline Sucrose & 2.50 & 2.50 & 2.50 & 2.50 \\
\hline Soybean oil & 2.60 & 2.60 & 2.30 & 2.30 \\
\hline Phospholipid powder & 1.50 & 1.50 & 1.50 & 1.50 \\
\hline Limestone & 0.29 & 0.29 & 0.29 & 0.29 \\
\hline Dicalcium phosphate & 0.67 & 0.67 & 0.69 & 0.69 \\
\hline Sodium chloride & 0.23 & 0.23 & 0.23 & 0.23 \\
\hline Lysine, 98\% & 0.57 & 0.57 & 0.8 & 0.8 \\
\hline Methionine & 0.25 & 0.25 & 0.35 & 0.35 \\
\hline Threonine & 0.31 & 0.31 & 0.42 & 0.42 \\
\hline Tryptophan & 0.10 & 0.10 & 0.14 & 0.14 \\
\hline Valine & 0.18 & 0.18 & 0.30 & 0.30 \\
\hline Isoleucine & 0.09 & 0.09 & 0.19 & 0.19 \\
\hline $\mathrm{ZnO}$ & 0.20 & 0.20 & 0.20 & 0.20 \\
\hline Activate $^{\circledast}$ DA & 0.50 & 0.50 & 0.50 & 0.50 \\
\hline Montmorillonite & 0.40 & 0.40 & 0.40 & 0.40 \\
\hline Feed antifungal agent & 0.05 & 0.05 & 0.05 & 0.05 \\
\hline Choline chloride & 0.12 & 0.12 & 0.12 & 0.12 \\
\hline Food attractant & 0.05 & 0.05 & 0.05 & 0.05 \\
\hline Premix* & 0.60 & 0.60 & 0.60 & 0.60 \\
\hline Carvacrol and thymol & & 0.05 & & 0.05 \\
\hline Total & 100 & 100 & 100 & 100 \\
\hline \multicolumn{5}{|l|}{ Nutrient content } \\
\hline Digestible energy, kcal/kg & 3463.00 & 3463.00 & 3458.60 & 3458.60 \\
\hline Crude protein, $\%$ & 18.00 & 18.00 & 17.98 & 17.98 \\
\hline Digestible lysine, \% & 1.35 & 1.35 & 1.50 & 1.50 \\
\hline Digestible methionine, \% & 0.62 & 0.62 & 0.71 & 0.71 \\
\hline Digestible threonine, \% & 0.88 & 0.88 & 0.97 & 0.97 \\
\hline Digestible tryptophan, \% & 0.27 & 0.27 & 0.30 & 0.30 \\
\hline Digestible valine, $\%$ & 0.87 & 0.87 & 0.96 & 0.96 \\
\hline $\mathrm{Ca}, \%$ & 0.50 & 0.50 & 0.49 & 0.49 \\
\hline Available P, \% & 0.36 & 0.36 & 0.36 & 0.36 \\
\hline
\end{tabular}

*Provided per kg of diet: Vitamin E $200 \mathrm{mg}$, Vitamin C $350 \mathrm{mg}$, piglet multidimensional $350 \mathrm{mg}$, piglet micromine $3000 \mathrm{mg}$, protein enzyme

(Cibenza ${ }^{\oplus}$ DP100) $100 \mathrm{mg}$, phytase $200 \mathrm{mg}$, microecological preparations 300 mg, antiseptic $1000 \mathrm{mg}$, antioxidants $200 \mathrm{mg}$, flavour $800 \mathrm{mg}$, sweetener 300 $\mathrm{mg}$, sodium butyrate $1500 \mathrm{mg}$
Table 2 Ingredients and nutrient composition of diet during 15 $\sim 42 \mathrm{~d}$

\begin{tabular}{|c|c|c|c|c|}
\hline \multirow[t]{2}{*}{ Composition, \% } & \multicolumn{2}{|c|}{ Low AA } & \multicolumn{2}{|c|}{ High AA } \\
\hline & $\mathrm{CB}(-)$ & $\mathrm{CB}(+)$ & $\mathrm{CB}(-)$ & $\mathrm{CB}(+)$ \\
\hline Corn & 30.40 & 30.35 & 31.40 & 31.35 \\
\hline Prepuffed raw materials & 33.04 & 33.04 & 32.99 & 32.99 \\
\hline Pretreatment raw materials & 7.00 & 7.00 & 7.00 & 7.00 \\
\hline Soybean meal, $46 \%$ CP & 5.40 & 5.40 & 4.00 & 4.00 \\
\hline Fermented soybean meal & 8.00 & 8.00 & 8.00 & 8.00 \\
\hline Brewer's yeast hydrolysate & 1.39 & 1.39 & 1.39 & 1.39 \\
\hline Low protein whey powder & 5.56 & 5.56 & 5.56 & 5.56 \\
\hline High protein whey powder & 1.39 & 1.39 & 1.39 & 1.39 \\
\hline Cheese whey & 0.69 & 0.69 & 0.69 & 0.69 \\
\hline Soybean oil & 1.90 & 1.90 & 1.60 & 1.60 \\
\hline Phospholipid powder & 0.50 & 0.50 & 0.50 & 0.50 \\
\hline Limestone & 0.80 & 0.80 & 0.80 & 0.80 \\
\hline Dicalcium phosphate & 0.82 & 0.82 & 0.84 & 0.84 \\
\hline Sodium chloride & 0.39 & 0.39 & 0.39 & 0.39 \\
\hline Lysine, 98\% & 0.58 & 0.58 & 0.82 & 0.82 \\
\hline Methionine & 0.17 & 0.17 & 0.27 & 0.27 \\
\hline Threonine & 0.26 & 0.26 & 0.38 & 0.38 \\
\hline Tryptophan & 0.08 & 0.08 & 0.12 & 0.12 \\
\hline Valine & 0.13 & 0.13 & 0.25 & 0.25 \\
\hline Isoleucine & 0.03 & 0.03 & 0.14 & 0.14 \\
\hline Feed antifungal agent & 0.05 & 0.05 & 0.05 & 0.05 \\
\hline Montmorillonite & 0.40 & 0.40 & 0.40 & 0.40 \\
\hline Choline chloride & 0.1 & 0.1 & 0.1 & 0.1 \\
\hline Food attractant & 0.05 & 0.05 & 0.05 & 0.05 \\
\hline Activate $^{\circledast}$ DA & 0.27 & 0.27 & 0.27 & 0.27 \\
\hline Premix * & 0.60 & 0.60 & 0.60 & 0.60 \\
\hline Carvacrol and thymol & & 0.05 & & 0.05 \\
\hline Total & 100 & 100 & 100 & 100 \\
\hline
\end{tabular}

Nutrient content

$\begin{array}{lllll}\text { Digestible energy, kcal/kg } & 3427.70 & 3427.70 & 3425.10 & 3425.10 \\ \text { Crude protein, \% } & 17.99 & 17.99 & 17.98 & 17.98 \\ \text { Digestible lysine, \% } & 1.25 & 1.25 & 1.40 & 1.40 \\ \text { Digestible methionine, \% } & 0.49 & 0.49 & 0.58 & 0.58 \\ \text { Digestible threonine, \% } & 0.81 & 0.81 & 0.91 & 0.91 \\ \text { Digestible tryptophan, \% } & 0.25 & 0.25 & 0.28 & 0.28 \\ \text { Digestible valine, \% } & 0.83 & 0.83 & 0.92 & 0.92 \\ \text { Ca, \% } & 0.60 & 0.60 & 0.59 & 0.59 \\ \text { Available P, \% } & 0.34 & 0.34 & 0.34 & 0.34\end{array}$

*Provided per kg of diet: Vitamin E $200 \mathrm{mg}$, Vitamin C $350 \mathrm{mg}$, piglet multidimensional $350 \mathrm{mg}$, piglet micromine $3000 \mathrm{mg}$, protein enzyme (Cibenza ${ }^{\oplus}$ DP100) 100 mg, phytase 200 mg, microecological preparations 300 $\mathrm{mg}$, antiseptic $1000 \mathrm{mg}$, antioxidants $200 \mathrm{mg}$, flavour $800 \mathrm{mg}$, sweetener 300 $\mathrm{mg}$, sodium butyrate $1500 \mathrm{mg}$ 
and the severity of diarrhea was evaluated by using the fecal consistency score system. In brief, scores were 0 , firm, normal; 1, pasty; slight diarrhea; 2, semi-liquid, moderate diarrhea; or 3, liquid and unformed, severe diarrhea $[19,20]$. The diarrhea rate was calculated as follows: Diarrhea rate $(\%)=$ (number of diarrhea weaned pigs)/(total number of experimental weaned pigs $\times$ experimental time $(\mathrm{d})) \times 100 \%$. Diarrhea index $=$ total fecal scores/total number of experimental weaned pigs.

\section{Sample collections}

At d 7 and 14, 2 pigs per pen were randomly selected for blood samples via the anterior vena cava puncture (tubes containing heparin sodium) and plasma was obtained after centrifugation at $900 \times g$ for $10 \mathrm{~min}$. The fresh fecal samples of the same weaned pigs were collected at the same time. Samples were frozen at $-80^{\circ} \mathrm{C}$ until analysis.

\section{Plasma and fecal chemical analysis}

$0.2 \mathrm{~g}$ of feces was weighed and put in the $1.5-\mathrm{mL}$ EP tube, $0.8 \mathrm{~mL}$ PBS was added, and it was homogenized on the mixer. After that, it was centrifuged at $400 \times g$ at $4{ }^{\circ} \mathrm{C}$ for $5 \mathrm{~min}$, and the supernatant was collected.

The activities of total superoxide dismutase (T-SOD), glutathione peroxidase (GSH-px), the plasma concentrations of malondialdehyde (MDA), antioxidative capacity (T-AOC) and plasma urea nitrogen (PUN) were detected using colorimetric methods with a spectrophotometer (Biomate 5, Rochester, NY, USA). The assays were carried out using commercial kits (Nanjing Jiancheng Bioengineering Institute, Nanjing, Jiangsu, China) and their corresponding procedures. The assays were performed in triplicate.

The level of plasma tumor necrosis factor $\alpha$ (TNF- $\alpha$ ), IL-1 $\beta$, IL-6, Interleukin 8 (IL-8) and the level of fecal Lipoprotein 2 were measured to evaluate the systemic and intestinal inflammatory response. The level of plasma endotoxin, D-lactate, diamine oxidase (DAO), and the level of fecal sIgA (P-KMLJ939189), MUC 2 were measured to evaluate the gut barrier function of weaned pigs. Pig TNF- $\alpha$ ELISA kit (2P-KMLJ942147p), IL-1 $\beta$ ELISA kit (2P-KMLJ941952p), IL-6 ELISA kit (PKMLJ941958p), IL-8 ELISA kit (2P-KMLJ941959p), Lipoprotein 2 (2P-KMLJ942831p), Endotoxin (2PKMLJ942056p), DAO (2P-KMLJ942522p), D-lactate (2PKMLJ942838p), sIgA (2P-KMLJ941995p), MUC 2 (2PKMLJ942137p) were purchased from Nanjing Camilo biological engineering Co., Ltd. (Camilo, Nanjing, China). Briefly, $10 \mu \mathrm{L}$ of plasma or fecal supernatant was added in the microplate. Add HRP-antibody solution and incubate at $37^{\circ} \mathrm{C}$. Then wash and add substrate solution. Incubate at $37^{\circ} \mathrm{C}$ in the dark. Add stop solution and measure absorbance at $450 \mathrm{~nm}$.

\section{Determinations of fecal SCFAs}

Fecal concentrations of short chain fatty acids (SCFAs) were determined as previously described [21], with slight modifications. In brief, approximately $0.1 \mathrm{~g}$ of fecal samples $(n=8-10 /$ group) was placed into $1.5-\mathrm{mL}$ centrifuge tubes, diluted with $1 \mathrm{~mL} 0.5 \%$ of phosphoric acid solution and homogenized. Then, the samples were centrifuged at $14,400 \times g$ for $10 \mathrm{~min}$ to obtain the supernatant. The supernatant was extracted with equal volume of ethyl acetate, and precipitated in refrigerator at $-20^{\circ} \mathrm{C}$. Then, the samples were centrifuged at $14,400 \times g$ for 10 min to obtain the supernatant. The concentrations of SCFAs in the supernatant were determined using gas chromatography (Thermo, Waltham, USA). All procedures were performed in duplicate.

\section{DNA extraction and real-time quantitative polymerase chain reaction (PCR)}

Total microbial DNA was extracted and purified from fecal samples on d 14 and 42 using a QIAamp DNA stool kit (TIANGEN, Beijing, China) according to the manufacturer's instructions. The quantity and quality of DNA was assessed using a NanoDropfi ND-1000 Spectrophotometer. Real-time quantitative polymerase chain reaction (PCR) analyses were performed by CFX ConnectTM Real-time PCR Detection System (Bio-Rad, Hercules, USA) in a final reaction volume of $10 \mu \mathrm{L}$ containing $4.4 \mu \mathrm{L}$ of template DNA $(50 \mathrm{ng} / \mu \mathrm{L}), 5 \mu \mathrm{L}$ iTaq $^{\text {th }}$ Universal SYBR Green Supermix (Bio-Rad, Hercules, USA) and $0.3 \mu \mathrm{L}$ of each of forward and reverse primers. Thermal cycling conditions involved an initial denaturation step at $95^{\circ} \mathrm{C}$ for $10 \mathrm{~min}$ followed by 40 cycles of denaturation at $95^{\circ} \mathrm{C}$ for $15 \mathrm{~s}$ and $65^{\circ} \mathrm{C}$ for $1 \mathrm{~min}$ [22]. Dissociation analyses of the PCR product were performed to confirm the specificity of the resulting PCR products. The primers used for the real-time PCR detection of selected genes are listed in Table 3.

\section{Statistical analysis}

All the data were analyzed using the general linear model (GLM) procedure of the Statistical Analysis. System (SAS 9.2 SAS Institute Inc., Cary, NC, USA). Data of the animal trial were statistically analyzed using the two-factor ANOVA to determine the main effects of dietary AA level, CB supplementation, and their interactions. If there was a main effect or the interaction was significant, the Bonferroni $t$-test was performed for post hoc comparison of means. The $X^{2}$ test was used to test for diarrhea rate. Data were expressed as means \pm standard error of the mean (SEM). Level of significance was set at $P<0.05$, whereas $0.05<P<0.1$ was considered a trend towards significance. 
Table 3 Primers used for absolute quantitative real-time polymerase chain reaction (PCR)

\begin{tabular}{lll}
\hline Target group & Sequence of primers, $\mathbf{5}^{\prime}$ to $\mathbf{3}^{\prime}$ & Size, bp \\
\hline Total bacteria & Forward: GTGSTGCAYGGYGTCGTCA & 146 \\
Lactobacillus spp. & Reverse: ACGTCRTCCMCNCCTTCCTC \\
Enterococcus & Forward: AGCAGTAGGGAATCTTCCA \\
& Reverse: CACCGCTACACATGGAG \\
Escherichia coli & Forward: CCCTTATTGTAGTTGCCATCATT \\
& Reverse: ACTCGTTGTACTTCCCATTGT \\
Bifidobacterium genus & Forward: CATGCCGCGTGTATGAAGA \\
& Reverse: CGGGTAACGTCAATGAGCAAA \\
& Forward: TCGCGTCTGGTGTGAAAG \\
& Reverse: CCACA TCCAGCATCCAC
\end{tabular}

\section{Results}

\section{Growth performance and diarrhea}

The growth performance and diarrhea rate of weaned pigs are shown in Table 4. There was not a significant interaction effect between AA level and CB supplementation on the growth performance $(P>0.05)$. During d 1 14 after weaning, high AA level significantly decreased ADFI and FCR of weaned pigs $(P<$
0.05). Dietary supplementation with $\mathrm{CB}$ significantly increased the final weight, ADG, ADFI and average daily lysine intake (ADLysI) $(P<0.05)$. There was a significant interaction effect between AA level and $\mathrm{CB}$ supplementation on the diarrhea rate $(P<0.05)$. During 15 42 d and 1 42 d after weaning, there was no significant difference in growth performance among different treatment groups.

Table 4 Growth performance of piglets

\begin{tabular}{|c|c|c|c|c|c|c|c|c|}
\hline \multirow[t]{2}{*}{ Items } & \multicolumn{2}{|l|}{ Low AA } & \multicolumn{2}{|c|}{ High AA } & \multirow[t]{2}{*}{ SEM } & \multicolumn{3}{|c|}{$P$-value } \\
\hline & CB (-) & $\mathrm{CB}(+)$ & $\mathrm{CB}(-)$ & $\mathrm{CB}(+)$ & & $\overline{A A}$ & $\mathrm{CB}$ & $A A \times C B$ \\
\hline Number of pens & 5 & 5 & 4 & 5 & & & & \\
\hline $1 \mathrm{~d} \mathrm{BW}, \mathrm{kg}$ & 7.74 & 7.75 & 7.74 & 7.77 & 0.01 & 0.60 & 0.40 & 0.91 \\
\hline $14 \mathrm{~d}$ BW, kg & 10.85 & 11.29 & 11.07 & 11.56 & 0.09 & 0.14 & $<0.01$ & 0.87 \\
\hline $42 \mathrm{~d}$ BW, kg & 29.38 & 29.34 & 28.87 & 29.14 & 0.32 & 0.56 & 0.85 & 0.80 \\
\hline \multicolumn{9}{|l|}{$1 \sim 14 d$} \\
\hline$A D G, g / d$ & 226.49 & 255.57 & 236.61 & 268.09 & 6.33 & 0.32 & 0.01 & 0.91 \\
\hline$A D F I, g / d$ & 340.91 & 372.02 & 311.59 & 343.63 & 8.41 & 0.04 & 0.03 & 0.97 \\
\hline ADLysl, g/d & 4.60 & 5.02 & 4.67 & 5.15 & 0.10 & 0.58 & 0.02 & 0.87 \\
\hline FCR & 1.51 & 1.46 & 1.32 & 1.29 & 0.03 & $<0.01$ & 0.31 & 0.91 \\
\hline Diarrhea rate, \% & $7.31^{\mathrm{a}}$ & $5.78^{a b}$ & $5.51 \mathrm{ab}$ & $5.24^{b}$ & 0.47 & 0.03 & 0.07 & 0.03 \\
\hline Diarrhea index & $0.18 \pm 0.04$ & 0.15 & 0.13 & 0.12 & 0.01 & 0.09 & 0.64 & 0.46 \\
\hline \multicolumn{9}{|l|}{$15 \sim 42 \mathrm{~d}$} \\
\hline$A D G, g / d$ & 657.21 & 642.87 & 632.62 & 628.98 & 8.28 & 0.28 & 0.61 & 0.76 \\
\hline ADFI, g/d & 899.44 & 905.25 & 899.84 & 888.96 & 16.46 & 0.82 & 0.94 & 0.81 \\
\hline ADLysl, g/d & 11.24 & 11.32 & 12.6 & 12.45 & 0.25 & 0.01 & 0.93 & 0.80 \\
\hline FCR & 1.37 & 1.41 & 1.42 & 1.41 & 0.01 & 0.98 & 0.72 & 0.39 \\
\hline \multicolumn{9}{|l|}{$1 \sim 42 \mathrm{~d}$} \\
\hline$A D G, g / d$ & 515.35 & 514.56 & 501.96 & 508.79 & 6.47 & 0.50 & 0.83 & 0.79 \\
\hline ADFI, g/d & 713.27 & 727.51 & 703.76 & 707.19 & 12.92 & 0.57 & 0.74 & 0.84 \\
\hline ADLysl, g/d & 7.92 & 8.17 & 8.64 & 8.80 & 0.15 & 0.03 & 0.48 & 0.89 \\
\hline FCR & 1.38 & 1.41 & 1.40 & 1.39 & 0.01 & 0.98 & 0.72 & 0.39 \\
\hline
\end{tabular}

All results are presented as mean \pm SEM. $A A$ Amino acid effect, $C B$ a carvacrol-thymol blend effect, $A A \times C B$ interaction effect of amino acid and a carvacrol-thymol blend, $A D L y s$ average daily lysine intake. $P<0.05$ significant difference, $P<0.01$ extremely significant difference 
The content of plasma urea nitrogen

As shown in Fig. 1, at d 14 after weaning, there was an interaction between AA level and $\mathrm{CB}$ supplementation on the content of PUN in weaned pigs $(P<0.05)$, which showed that high level AA dietary supplemented with CB significantly reduced the content of PUN $(P<0.05)$, but not compared to low AA $(P>0.05)$. At $d 7$ after weaning, high AA level significantly $(P<0.05)$ reduced the content of PUN.

\section{Antioxidant activity and lipid peroxidation in plasma}

As shown in Table 5. There was no interaction between AA level and a carvacrol-thymol blend on antioxidant enzyme activity and MDA content in plasma of weaned pigs. Dietary supplementation with $\mathrm{CB}$ significantly $(P<$ 0.05 ) increased the plasma T-SOD activity at $\mathrm{d} 7$ after weaning and GSH-px activity at d 14 after weaning, and significantly decreased the plasma MDA content at $\mathrm{d} 7$ and d 14 after weaning $(P<0.05)$. Different AA levels had no significant $(P>0.05)$ effects on antioxidant enzyme activity and MDA content in plasma of weaned pigs.

\section{Level of inflammatory factors in plasma and feces}

As shown in Fig. 2. There was no interaction between AA level and a carvacrol-thymol blend on the content of inflammatory factors in weaned pigs. High AA level significantly reduced the content of plasma IL- 6 and fecal lipoprotein-2 at d 14 after weaning (Fig. 2C \& E) $(P<0.05)$; Dietary supplementation with $\mathrm{CB}$ significantly reduced the content of fecal lipoprotein 2 at $\mathrm{d} 7$ after weaning and plasma IL-1 $\beta$ at $\mathrm{d} 14$ after weaning (Fig. 2B \& E) $(P<0.05)$.

\section{Selected fecal bacterial populations}

As shown in Fig. 3. At d 14 after weaning, increasing dietary AA level significantly increased the relative abundance of fecal Enterococcus and Lactobacillus $(P<0.05)$ (Fig. 3B \& C); Dietary supplementation with CB significantly reduced the relative abundance of fecal Escherichia coli $(P<0.05)$ (Fig. 3A). Whereas, there are not significant effects on selected fecal bacterial populations with high AA level and dietary supplementation with $\mathrm{CB}$ at $\mathrm{d} 7$ after weaning $(P>0.05)$ (Fig. 3$)$.

\section{Fecal SCFAs}

As shown in Fig. 4. There was no interaction between AA level and a carvacrol-thymol blend on the content of SCFAs in piglet feces. High AA level tended to increase the content of isovaleric acid and total branched chain fatty acids (isobutyric acid and isovaleric acid) at $\mathrm{d}$ 14 after weaning (Fig. 4B) $(P<0.1)$. Dietary supplementation with $\mathrm{CB}$ had no significant $(P>0.05)$ effects on the content of SCFAs in piglet feces (Fig. 4).

\section{Biomarkers of intestinal barrier function}

The biomarkers of intestinal barrier function were shown in Fig. 5. At d 7 after weaning, there was a trend of interaction between AA level and a carvacrol-thymol blend on endotoxin content in plasma (Fig. 5A) $(P<0.1)$.

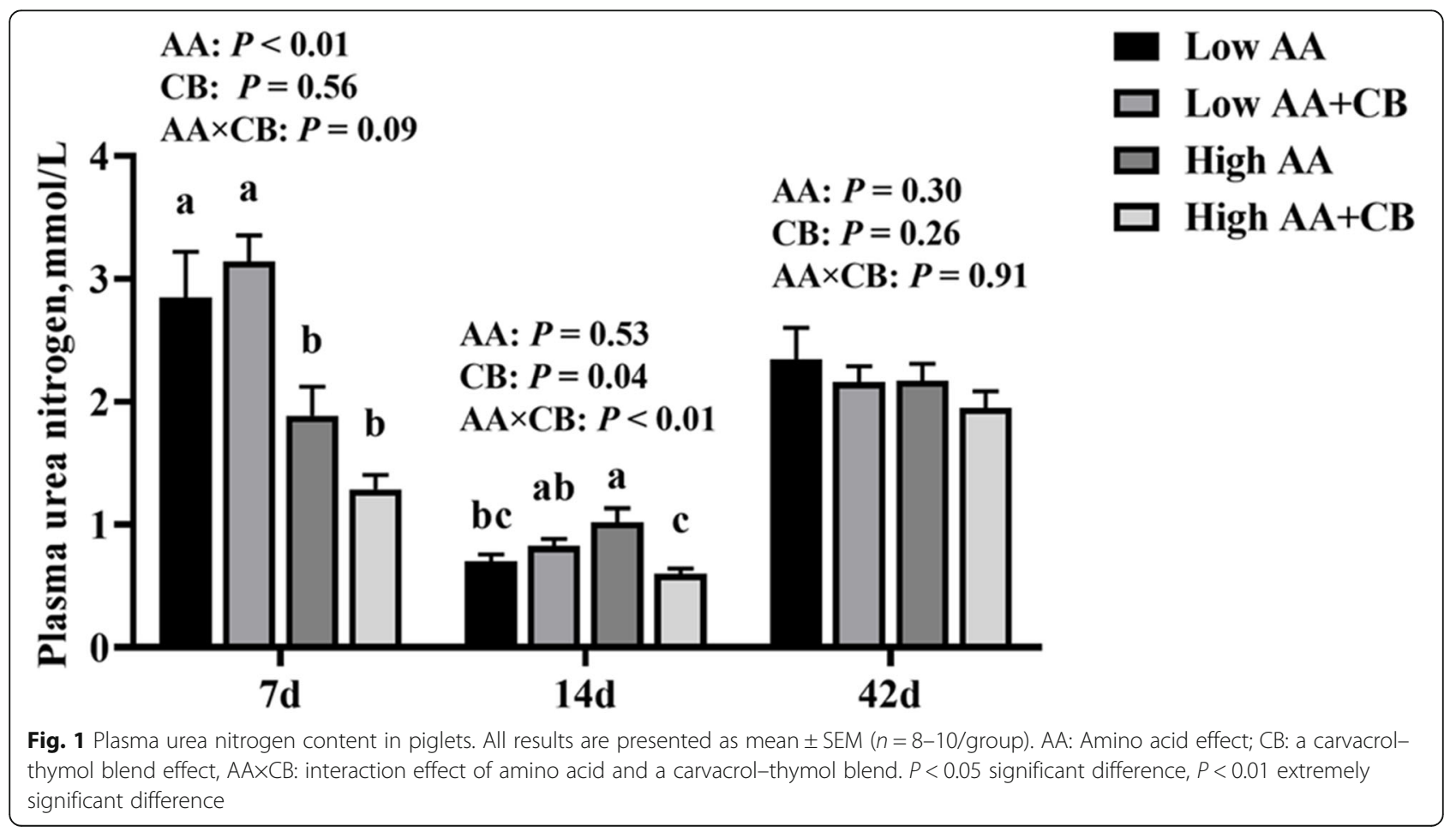


Table 5 Antioxidant enzyme activity and MDA content in plasma of piglets

\begin{tabular}{|c|c|c|c|c|c|c|c|c|c|}
\hline \multirow[t]{2}{*}{ Times } & \multirow[t]{2}{*}{ Items } & \multicolumn{2}{|l|}{ Low AA } & \multicolumn{2}{|c|}{ High AA } & \multirow[t]{2}{*}{ SEM } & \multicolumn{3}{|c|}{$P$-value } \\
\hline & & $\mathrm{CB}(-)$ & $\overline{C B}(+)$ & $\mathrm{CB}(-)$ & $\overline{C B(+)}$ & & $\overline{\mathrm{AA}}$ & $\mathrm{CB}$ & $\overline{A A \times C B}$ \\
\hline & Number of pens & 10 & 10 & 8 & 10 & & & & \\
\hline \multirow[t]{4}{*}{$7 d$} & T-SOD, U/mL & 25.94 & 37.39 & 33.18 & 40.07 & 1.83 & 0.15 & 0.01 & 0.50 \\
\hline & GSH-px, $\mu \mathrm{mol} / \mathrm{L}$ & 1023.54 & 992.86 & 998.93 & 935.54 & 20.77 & 0.34 & 0.27 & 0.70 \\
\hline & $\mathrm{MDA}, \mathrm{nmol} / \mathrm{mL}$ & 6.96 & 5.81 & 7.33 & 6.52 & 0.24 & 0.26 & 0.04 & 0.72 \\
\hline & $\mathrm{T}-\mathrm{AOC}, \mathrm{U} / \mathrm{mL}$ & 0.76 & 0.75 & 0.75 & 0.79 & 0.01 & 0.38 & 0.59 & 0.12 \\
\hline \multirow[t]{4}{*}{$14 d$} & T-SOD, U/mL & 42.37 & 38.33 & 35.58 & 37.69 & 1.28 & 0.16 & 0.71 & 0.24 \\
\hline & GSH-px, $\mu \mathrm{mol} / \mathrm{L}$ & 576.94 & 644.94 & 610.51 & 694.28 & 16.94 & 0.20 & 0.02 & 0.81 \\
\hline & $\mathrm{MDA}, \mathrm{nmol} / \mathrm{mL}$ & 7.35 & 5.52 & 7.52 & 6.77 & 0.27 & 0.17 & 0.02 & 0.30 \\
\hline & $\mathrm{T}-\mathrm{AOC}, \mathrm{U} / \mathrm{mL}$ & 0.71 & 0.71 & 0.71 & 0.7 & 0.01 & 1.00 & 0.33 & 0.83 \\
\hline
\end{tabular}

All results are presented as mean \pm SEM. $A A$ Amino acid effect, $C B$ a carvacrol-thymol blend effect, $A A \times C B$ interaction effect of amino acid and a carvacrol-thymol blend. $P<0.05$ significant difference, $P<0.01$ extremely significant difference

Dietary supplementation with $\mathrm{CB}$ significantly decreased plasma endotoxin at low AA level $(P<0.05)$. High AA level had a tendency to increase fecal sIgA and fecal MUC 2 contents at d 7 after weaning (Fig. 5D \& E) $(P<$ 0.1 ). Dietary supplementation with $\mathrm{CB}$ significantly reduced plasma endotoxin and $D$-lactic acid content at $\mathrm{d}$ 7,14 and $\mathrm{d} 7$ after weaning respectively $(P<0.05)$ (Fig. $5 \mathrm{~A} \& \mathrm{~B})$. At d 14 after weaning, there was an interaction between AA level and a carvacrol-thymol blend on plasma endotoxin and $D$-lactic acid content (Fig. 5A \& B) $(P<0.05)$. Low level of AA diet supplemented with $\mathrm{CB}$ significantly reduced the content of endotoxin in plasma at d 14 after weaning $(P<0.01)$ (Fig. 5A). Dietary supplementation with $\mathrm{CB}$ had a tendency to increase the content of SIgA in feces at d 14 after weaning $(P=0.05)$ (Fig. 5D).

\section{Discussion}

Essential AA are precursors of many bioactive substances and play an important role in promoting the growth of animals [23, 24]. High AA level significantly reduced ADFI and FCR of weaned pigs, which may be related to the transport of AA. Studies have shown that reducing dietary lysine level inhibited the expression of lysine transporter and the transport of lysine in the intestine, which promoted the feed uptake of piglets [25].

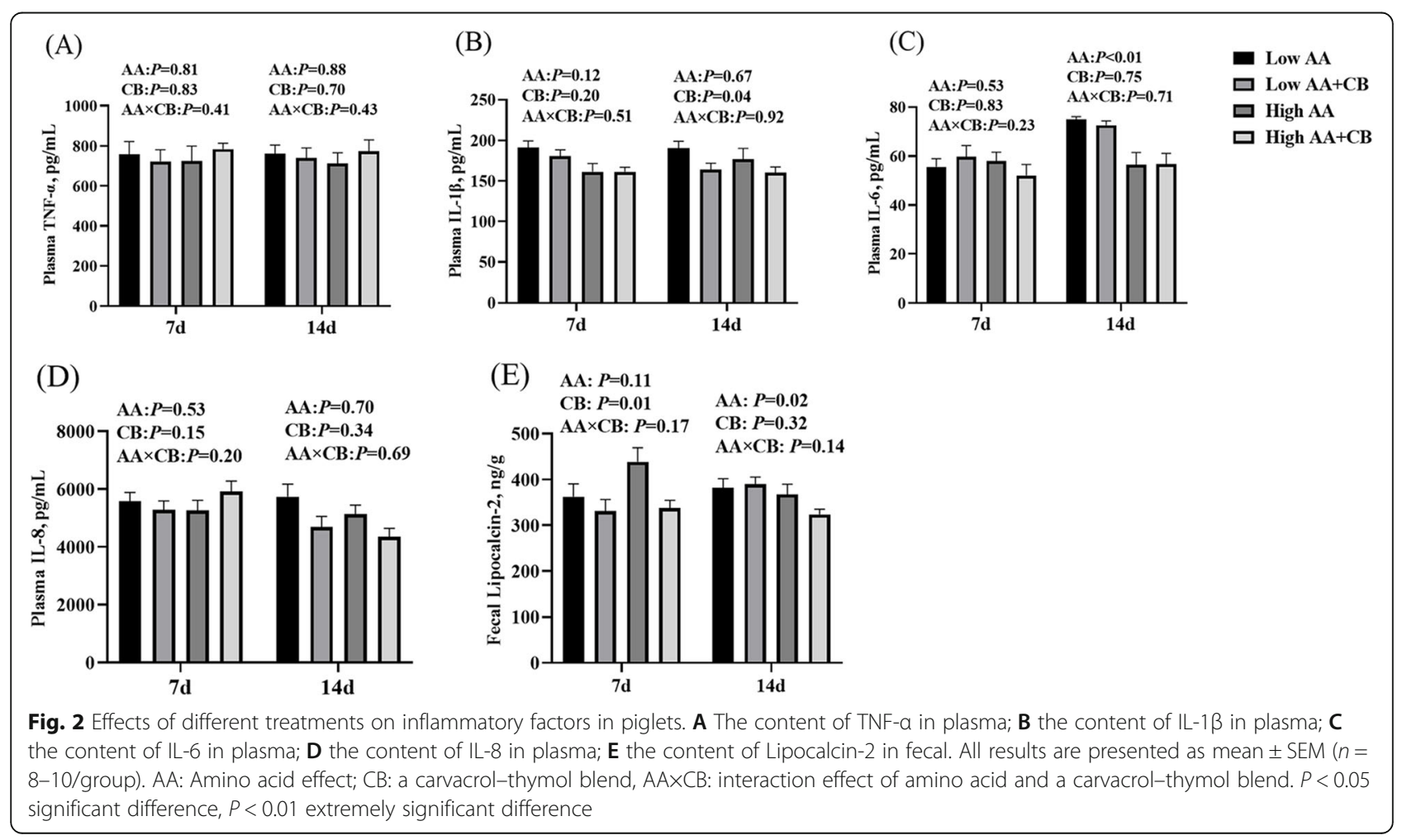



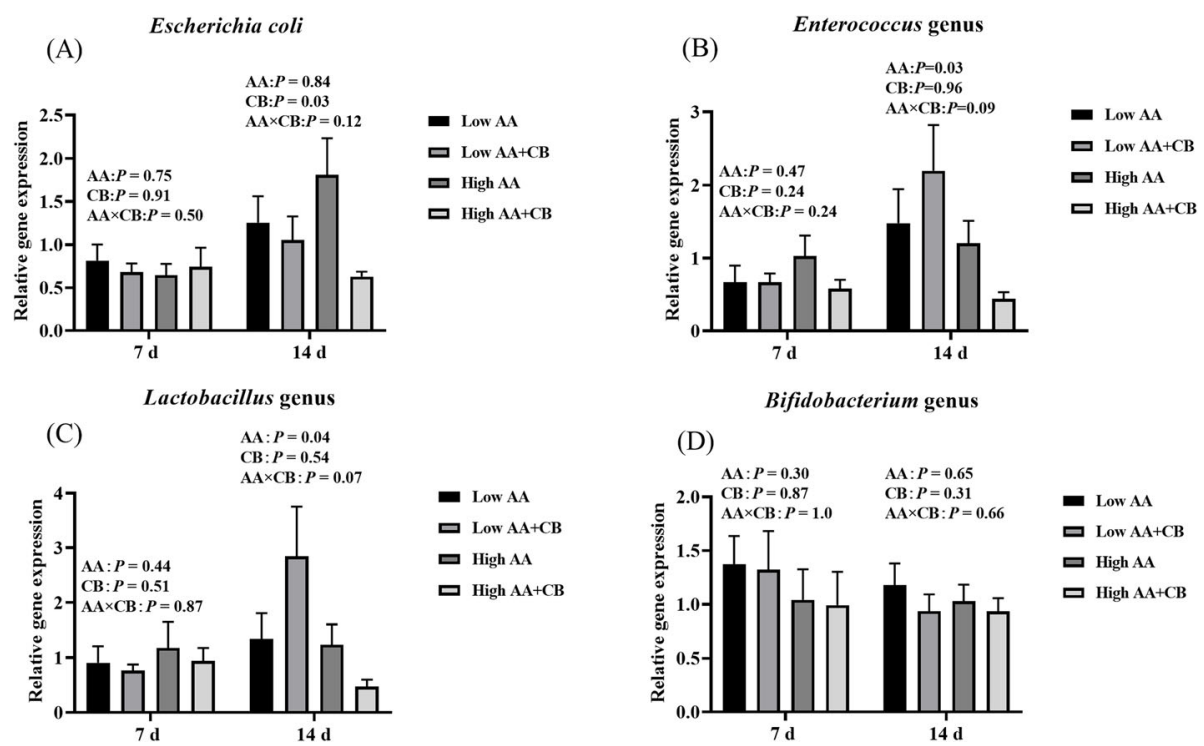

Fig. 3 Effects of different treatments on specific microorganisms in piglet feces. Relative abundance of $\mathbf{A}$ E. coli, B Enterococcus, C Lactobacillus and $\mathbf{D}$ Bifidobacterium in piglet feces. All results are presented as mean \pm SEM ( $n=8-10 / g r o u p)$. AA: Amino acid effect; CB: a carvacrol-thymol blend effect, $A A \times C B$ : interaction effect of amino acid and a carvacrol-thymol blend. $P<0.1$ indicates the tendency of significant difference, $P<$ 0.05 significant difference

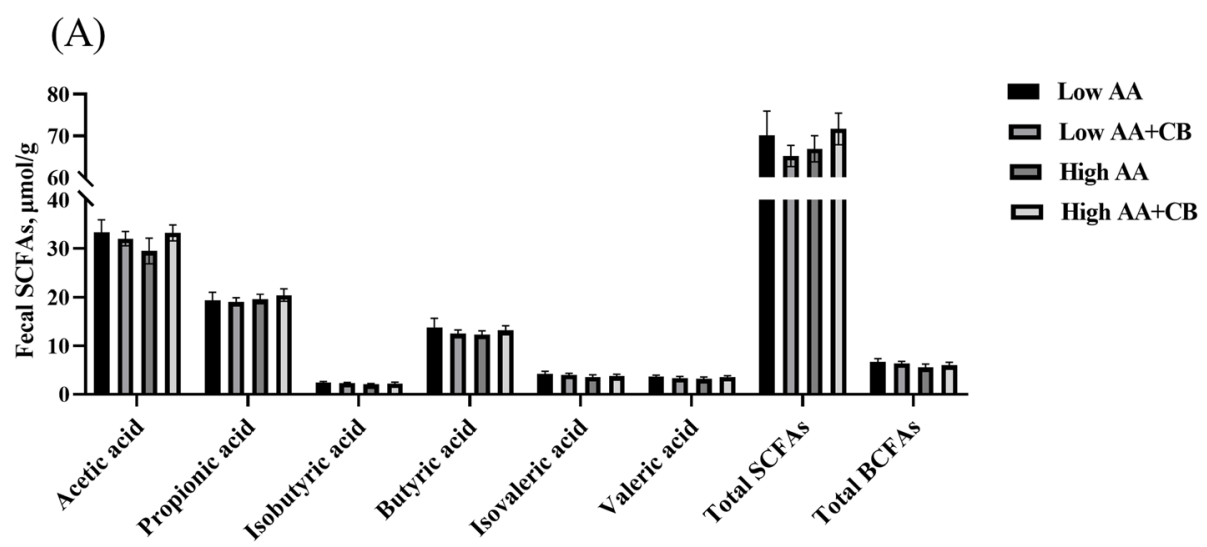

(B)

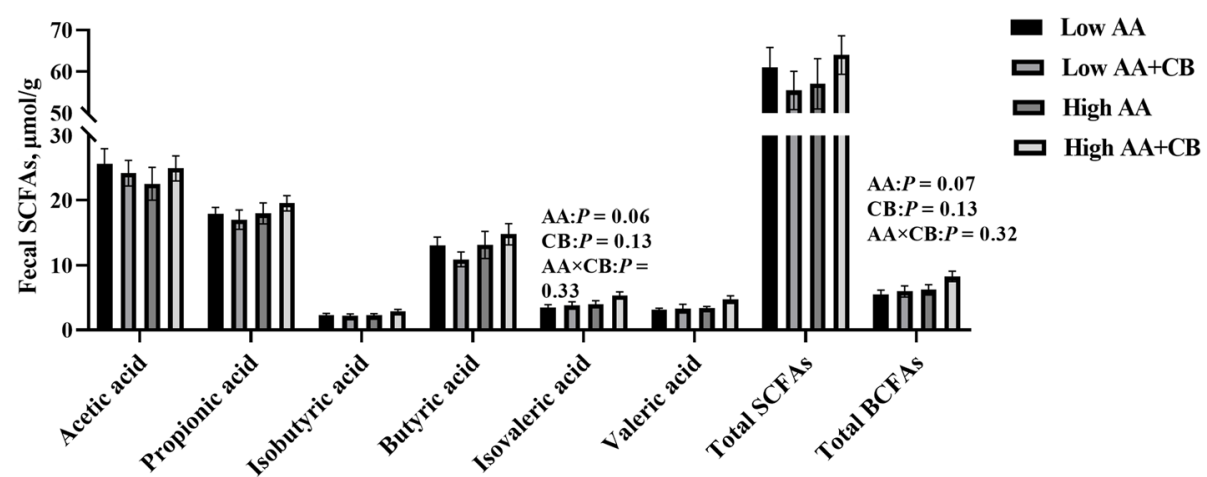

Fig. 4 Concentrations of SCFAs in piglet feces. A The content of SCFAs in feces of piglets on $\mathbf{d} 7$ after weaning; $\mathbf{B}$ the content of SCFAs in feces of piglets on $\mathrm{d} 14$ after weaning. All results are presented as mean \pm SEM ( $n=8-10 /$ group). AA: Amino acid effect; CB: a carvacrol-thymol blend effect, $A A \times C B$ : interaction effect of amino acid and a carvacrol-thymol blend. $P<0.1$ indicates the tendency of significant difference 

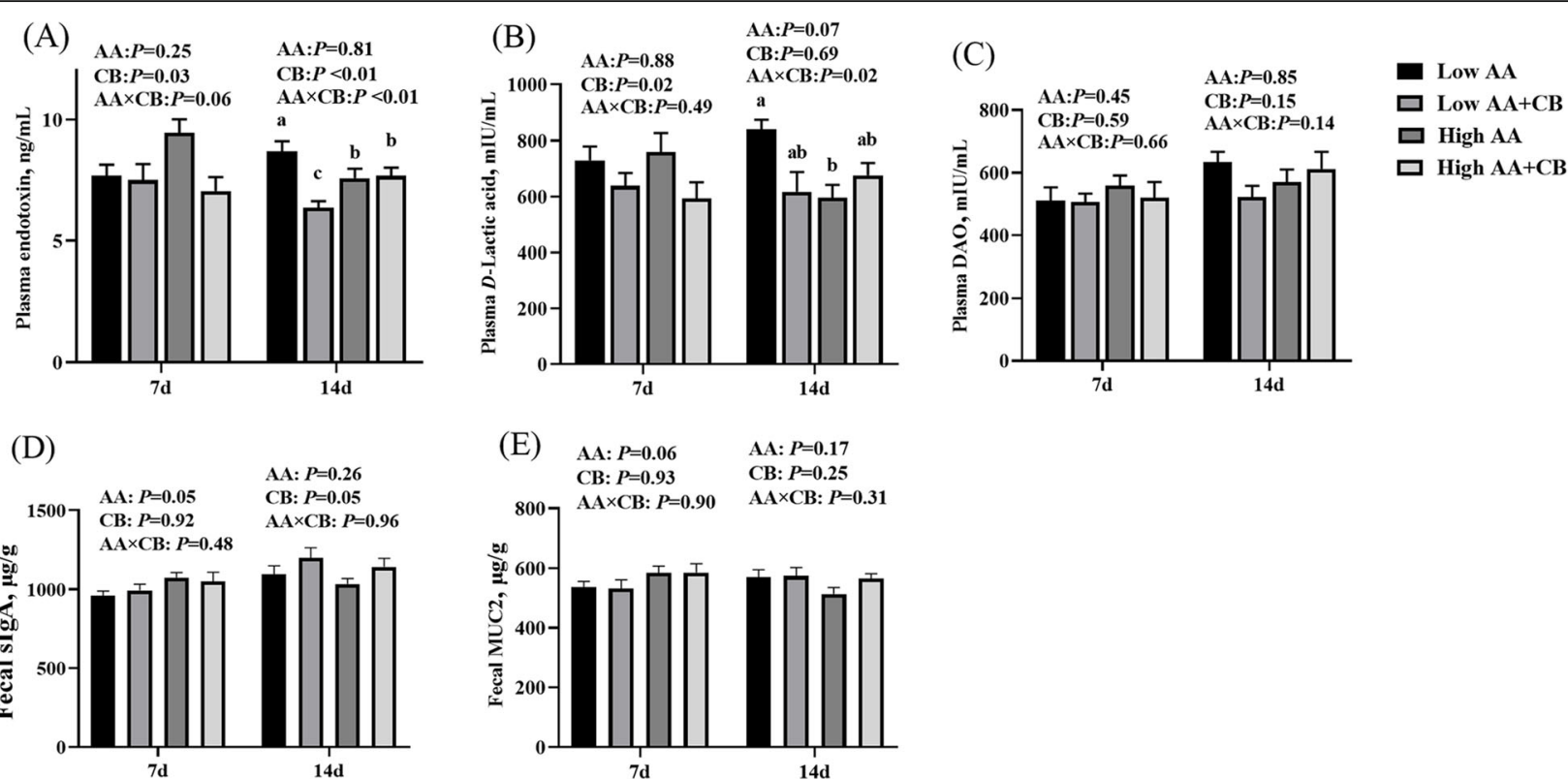

Fig. 5 Effects of different treatments on intestinal barrier function in piglets. A The content of endotoxin in plasma; B the content of D-lactic acid in plasma; $\mathbf{C}$ the content of DAO in plasma; $\mathbf{D}$ the content of secretory immunoglobulin A content in fecal; $\mathbf{E}$ the content of MUC 2 in fecal. All results are presented as mean \pm SEM ( $n=8-10$ /group). AA: Amino acid effect; CB: a carvacrol-thymol blend effect, AAxCB: interaction effect of amino acid and a carvacrol-thymol blend. $P<0.1$ indicates the tendency of significant difference, $P<0.05$ significant difference, $P<0.01$ extremely significant difference

The decrease of FCR during the first two weeks postweaning may be related to the decrease of PUN content. PUN is an important index to evaluate the nitrogen utilization rate, the lower level of PUN, the higher the nitrogen utilization rate of animal body in protein synthesis $[26,27]$. Therefore, increasing the level of AA may improve the FCR of weaned pigs by increasing the utilization rate of AA.

Our results showed that dietary supplementation $\mathrm{CB}$ significantly increased BW, ADG, ADLysI and ADFI of weaned pigs, but had no significant effect on FCR of weaned pigs. We hypothesis dietary supplementation $\mathrm{CB}$ decreased the content of PUN to elevated the utilize of AA in piglet thus to promote the growth performance. Other studies also demonstrated that the content of PUN in weaned pigs was significantly reduced by feeding carvacrol and thymol diets [18]. In addition, this study found that dietary supplementation $\mathrm{CB}$ improved the growth performance of weaned pigs primarily in the early stage of the experiment, probably because the effects of weaning on the intestinal structure of weaned pigs was mainly in the early stage of weaning [28].

Early weaning pigs are affected by diet changes, environmental, physiological and psychological factors, are prone to slow growth, diarrhea, intestinal barrier function damage and other weaning stress problems, which may have negative effects on the health and growth of weaned pigs [29-31]. The increasing content of plasma endotoxin and $D$-lactic acid are a marker of increased intestinal permeability. Endotoxin as a component of the exterior cell wall of Gram-negative bacteria, the abundance of endotoxin in plasma presents enhanced intestinal permeability and poor intestinal barrier function $[32,33] . D$-lactic acid is a metabolic product of bacterial fermentation, which can be produced by a variety of intestinal bacteria. When intestinal mucosal permeability increases, a large amount of $D$-lactic acid produced by intestinal bacteria enters the blood through the damaged mucosa, increasing the serum $D$-lactic acid level $[34,35]$. In the present study, supplementation with $\mathrm{CB}$ decreased plasma concentrations of endotoxins and $D$ lactate at $\mathrm{d}$ 7, 14 and $\mathrm{d} 7$ after weaning respectively. At $\mathrm{d}$ 14 after weaning, there was an interaction between AA level and a carvacrol-thymol blend on plasma endotoxin and $D$-lactic acid content. These results indicated that the effects of $\mathrm{CB}$ on intestinal permeability of weaned pigs are not consistent at different AA levels, and there may be obvious differences of mechanisms.

Adequate AA intake is particularly important for intestinal physiology of weaned pigs [36]. We found that high AA level significantly reduced fecal lipoprotein-2 content, and had a tendency to increase fecal MUC 2 and sIgA. Fecal Lipocalin 2 is a biomarker for intestinal inflammation [37]. Mucin secreted by goblet cells, especially MUC 2 plays an important role in maintaining 
intestinal mucosal barrier function [38]. In the small intestine, sIgA can directly reflect the immune barrier function of intestinal mucosa [39]. These results indicated that dietary AA levels might alleviate the intestinal inflammatory reaction, improved the intestinal immune and chemical barrier function of weaned pigs.

Intestinal oxidative stress and inflammatory response during weaning are one of the reasons for the impairment of intestinal barrier function [40,41]. The results showed that dietary supplementation with CB significantly alleviated the oxidative stress induced by weaning. Carvacrol and thymol have strong antioxidant activity and play an important role in scavenging free radicals and peroxynitrite and inhibiting lipid peroxidation [42, 43]. The phenolic hydroxyl groups contained in carvacrol and thymol can act as hydrogen donors to bind with peroxy radical and block the oxidative chain reaction, thus preventing and delaying lipid oxidation [44]. Carvacrol and thymol are the main role in the antioxidant function in oragno essienal oil [45], Our previous studies also found that dietary supplementation with $\mathrm{CB}$ or oragno essienal oil had antioxidant function in piglets [16], growing finishing pigs [46], sows [47] and boars [48]. In addition, we also found that the relative abundance of fecal Escherichia coli was significantly reduced by dietary supplementation with CB. Dietary supplementation with $\mathrm{CB}$ can reduce the relative abundance of free radical producing bacteria such as Escherichia coli in piglets' intestines [16]. The deamination of valine and leucine by bacteria produces isobutyric acid and isoprene, which are the markers of protein fermentation [49]. Although high AA level had the tendency to increase the fecal isoprene and total branched chain fatty acids, but it did not increase diarrhea or damage the intestinal health of weaned pigs. Therefore, dietary supplementation with $\mathrm{CB}$ improved intestinal permeability may be related to alleviating oxidative stress in weaned pigs.

\section{Conclusion}

The improvement of dietary AA level mainly affected the utilization of AA in early stage after weaning, and improved the intestinal barrier function of weaned pigs, which could alleviate diarrhea and promote the growth of weaned pigs. Dietary supplementation with $C B$ could reduce the relative abundance of harmful bacteria and improve the integrity of intestinal structure of weaned pigs by reducing oxidative stress and inflammatory response of the body, and then promoting the growth of weaned pigs. The weaned pigs will reach the best growth rate in 2 weeks after weaning by increasing the level of dietary Lys at $1.5 \%$ and $1.4 \%$ together with supplementation with $\mathrm{CB}$.

\section{Abbreviations}

ADG: Average daily gain; ADFI: Average daily feed intake; BCFAs: Branched chain fatty acid; CB: Carvacrol-thymol blend; DAO: Diamineoxidase;
FCR: Feed conversion ratio; GSH-PX: Glutathione peroxidase; IL1ß: Interleukin-1ß; IL-6: Interleukin-6; IL-8: Interleukin-8; IGF: Insulin-like growth factor; MCFAs: Medium chain fatty acids; MDA: Malonaldehyde; MUC 2: Mucin 2; OAs: Organic acids; PUN: Plasma urea nitrogen; SCFAs: Short chain fatty acids; slgA: Secreted immunoglobin A

\section{Acknowledgements}

We thank Yangxiang Co., Ltd. (China) and Novus International Trading (Shanghai) Co., Ltd. for technical assistance.

\section{Authors' contributions}

The author' contributions are as follows: HKW was in charge of the whole trial; YNW and YFZ for animal feeding and sample collections; JJT, HQS, DFS, YYM offered the technical support for ingredient composition and participating in the revision of manuscript; YNW and ZPY analyzed experimental data and wrote the manuscript; YNW and ZPY assisted with laboratory analyses; All authors read and approved the final manuscript.

\section{Funding}

This work was supported by Hubei Province Science and Technology Innovation Major Project (2019ABA081, 2021BBA083); China Agriculture Research System of MOF and MARA.

\section{Availability of data and materials}

The datasets used and/or analysed during the current study are available from the corresponding author on reasonable request.

\section{Declarations}

Ethics approval and consent to participate

The protocol of the experiment was approved by the Huazhong Agricultural University Institutional Animal Care and Use Committee and performed in accordance with national guidelines.

Consent for publication

Not applicable.

\section{Competing interests \\ None}

\section{Author details}

${ }^{1}$ Department of Animal Nutrition and Feed Science, College of Animal Science and Technology, Huazhong Agricultural University, Wuhan 430070, China. ${ }^{2}$ Guangxi Yangxiang Co., Ltd, Guigang 537000, China. ${ }^{3}$ Novus International Trading (Shanghai) Co. Ltd, Shanghai 200080, China. ${ }^{4}$ The Cooperative Innovation Center for Sustainable Pig Production, Wuhan 430070, China.

Received: 24 September 2021 Accepted: 5 January 2022

Published online: 08 March 2022

\section{References}

1. Laxminarayan R, Duse A, Wattal C, Zaidi AKM, Wertheim HFL, Sumpradit N, et al. Antibiotic resistance-the need for global solutions. Lancet Infect Dis. 2013;13(12):1057-98. https://doi.org/10.1016/S1473-3099(13)70318-9.

2. Makary MA, Kaczmarski K, Nachman K. A call for doctors to recommend antibiotic-free foods: agricultural antibiotics and the public health crisis of antimicrobial resistance. J Antibiot. 2018;71(8):685-7. https://doi.org/10.1038/ s41429-018-0062-y.

3. Shang Q, Liu H, Wu D, Mahfuz S, Piao X. Source of fiber influences growth, immune responses, gut barrier function and microbiota in weaned piglets fed antibiotic-free diets. Anim Nutr. 2021;7(2):315-25. https://doi.org/10.10 6/j.aninu.2020.12.008.

4. BR MC, Duttlinger AW, Kpodo KR, Eicher SD, Richert BT, Johnson JS. Replacing dietary antibiotics with $0.20 \% \mathrm{~L}$-glutamine and synbiotics following weaning and transport in pigs. J Anim Sci. 2020;98(9):skaa272.

5. Stoll B, Henry J, Reeds PJ, Yu H, Jahoor F, Burrin DG. Catabolism dominates the first-pass intestinal metabolism of dietary essential amino acids in milk proteinfed piglets. J Nutr. 1998;128(3):606-14. https://doi.org/10.1093/jn/128.3.606. 
6. Broer S. Apical transporters for neutral amino acids: physiology and pathophysiology. Physiology. 2008;23(2):95-103. https://doi.org/10.1152/ physiol.00045.2007.

7. Dai ZL, Zhang J, Wu GY, Zhu WY. Utilization of amino acids by bacteria from the pig small intestine. Amino Acids. 2010;39(5):1201-15. https://doi. org/10.1007/s00726-010-0556-9.

8. Dai ZL, Li XL, Xi PB, Zhang J, Wu GY, Zhu WY. Metabolism of select amino acids in bacteria from the pig small intestine. Amino Acids. 2012;42(5):1597608. https://doi.org/10.1007/s00726-011-0846-x.

9. Schlomann B, Wiles T, Wall E, Guillemin K, Parthasarathy R. Sublethal antibiotics collapse gut bacterial populations by enhancing aggregation and expulsion. Proc Natl Acad Sci U S A. 2019;116(43):21392-400. https:// doi.org/10.1073/pnas.1907567116.

10. Kahindi RK, Htoo JK, Nyachoti CM. Short Communication: Effect of dietary lysine content and sanitation conditions on performance of weaned pigs fed antibiotic-free diets. Can J Anim Sci. 2014;94(1):115-8. https://doi.org/1 0.4141/Cjas2013-016.

11. Zhou JY, Wang YM, Zeng XZ, Zhang T, Li PL, Yao BQ, et al. Effect of antibiotic-free, low-protein diets with specific amino acid compositions on growth and intestinal flora in weaned pigs. Food Funct. 2020;11(1):493-507. https://doi.org/10.1039/c9fo02724f.

12. Jayaraman B, Htoo JK, Nyachoti CM. Effects of different dietary tryptophan: lysine ratios and sanitary conditions on growth performance, plasma urea nitrogen, serum haptoglobin and ileal histomorphology of weaned pigs. Anim Sci J. 2017;88(5):763-71. https://doi.org/10.1111/asj.12695.

13. Tapia-Rodriguez MR, Hernandez-Mendoza A, Gonzalez-Aguilar GA, MartinezTellez MA, Martins CM, Ayala-Zavala JF. Carvacrol as potential quorum sensing inhibitor of Pseudomonas aeruginosa and biofilm production on stainless steel surfaces. Food Control. 2017;75:255-61. https://doi.org/10.101 6/j.foodcont.2016.12.014

14. Zou Y, Wang J, Peng J, Wei H. Oregano essential oil induces SOD1 and GSH expression through Nrf2 activation and alleviates hydrogen peroxideinduced oxidative damage in IPEC-J2 cells. Oxid Med Cell Longev. 2016; 2016:5987183. https://doi.org/10.1155/2016/5987183.

15. da Silva LM, Quintans-Júnior LJ, de Santana WA, Kaneto CM, Soares MBP, Villarreal CF. Anti-inflammatory effects of carvacrol: evidence for a key role of interleukin-10. Eur J Pharmacol. 2013;699(1-3):112-7. https://doi.org/10.1 016/j.ejphar.2012.11.040.

16. Wei H-K, Xue H-X, Zhou Z, Peng J. A carvacrol-thymol blend decreased intestinal oxidative stress and influenced selected microbes without changing the messenger RNA levels of tight junction proteins in jejunal mucosa of weaning piglets. Animal. 2017;11(2):193-201. https://doi.org/10.1 017/S1751731116001397.

17. Rossi B, Toschi A, Piva A, Grilli E. Single components of botanicals and nature-identical compounds as a non-antibiotic strategy to ameliorate health status and improve performance in poultry and pigs. Nutr Res Rev. 2020;33(2):218-34. https://doi.org/10.1017/S0954422420000013.

18. Tan BF, Lim T, Boontiam W. Effect of dietary supplementation with essential oils and a Bacillus probiotic on growth performance, diarrhoea and blood metabolites in weaned pigs. Anim Prod Sci. 2021;61(1):64-71. https://doi. org/10.1071/An18752.

19. Xiang QH, Wu XY, Pan Y, Wang L, Guo YW, Cui CB, et al. Early intervention using fecal microbiota transplantation combined with probiotics influence the growth performance, diarrhea, and intestinal barrier function of piglets. Appl Sci. 2020;10(2):568. https://doi.org/10.3390/app10020568.

20. Hermann-Bank ML, Skovgaard K, Stockmarr A, Strube ML, Larsen N, Kongsted $\mathrm{H}$, et al. Characterization of the bacterial gut microbiota of piglets suffering from new neonatal porcine diarrhoea. BMC Vet Res. 2015;11(1):119. https://doi.org/10.1186/s12917-015-0419-4

21. Garcia-Villalba R, Gimenez-Bastida JA, Garcia-Conesa MT, TomasBarberan FA, Espin JC, Larrosa M. Alternative method for gas chromatography-mass spectrometry analysis of short-chain fatty acids in faecal samples. J Sep Sci. 2012;35(15):1906-13. https://doi.org/10.1 002/jssc.201101121.

22. H-k W, Chen G, Wang R-J, Peng J. Oregano essential oil decreased susceptibility to oxidative stress-induced dysfunction of intestinal epithelial barrier in rats. J Funct Foods. 2015;18:1191-9. https://doi.org/10.1155/2016/ 5987183.

23. Mou Q, Yang HS, Yin YL, Huang PF. Amino acids influencing intestinal development and health of the piglets. Anim-Basel. 2019;9(6):302. https:// doi.org/10.3390/ani9060302.
24. Wu GY, Bazer FW, Dai ZL, Li DF, Wang JJ, Wu ZL. Amino acid nutrition in animals: protein synthesis and beyond. Annu Rev Anim Biosci. 2014;2:387417. https://doi.org/10.1146/annurev-animal-022513-114113.

25. Yin J, Han H, Li YY, Liu ZJ, Zhao YR, Fang RJ, et al. Lysine restriction affects feed intake and amino acid metabolism via gut microbiome in piglets. Cell Physiol Biochem. 2017:44(5):1749-61. https://doi.org/10.1159/000485782.

26. Hong J, Kim H-S, Do S, Kim H-J, Kim S-W, Jang S-K, et al. Effects of lysine cell mass supplementation as a substitute for L-lysine $\mathrm{HCl}$ on growth performance, diarrhea incidence, and blood profiles in weaning pigs. AnimBasel. 2021;11(7):2092. https://doi.org/10.3390/ani11072092.

27. Eggum $\mathrm{BO}$. Blood urea measurement as a technique for assessing protein quality. Br J Nutr. 1970;24(4):983. https://doi.org/10.1079/bjn19700101.

28. Moeser AJ, Vander Klok C, Ryan KA, Wooten JG, Little D, Cook VL, et al. Stress signaling pathways activated by weaning mediate intestinal dysfunction in the pig. Am J Physiol Gastrointest Liver Physiol. 2007;292(1): G173-G81. https://doi.org/10.1152/ajpgi.00197.2006.

29. Xiong $X$, Tan B, Song M, Ji P, Kim K, Yin YL, et al. Nutritional intervention for the intestinal development and health of weaned pigs. Front Vet Sci. 2019; 6:46. https://doi.org/10.3389/fvets.2019.00046.

30. Hu CH, Xiao K, Luan ZS, Song J. Early weaning increases intestinal permeability, alters expression of cytokine and tight junction proteins, and activates mitogen-activated protein kinases in pigs. J Anim Sci. 2013;91(3): 1094-101. https://doi.org/10.2527/jas.2012-5796.

31. Moeser AJ, Pohl CS, Rajput M. Weaning stress and gastrointestinal barrier development: implications for lifelong gut health in pigs. Anim Nutr. 2017; 3(4):313-21. https://doi.org/10.1016/j.aninu.2017.06.003.

32. Xie $W$, Song $L$, Wang $X, X u Y$, Liu Z, Zhao D, et al. A bovine lactoferricinlactoferrampin-encoding Lactobacillus reuteri CO21 regulates the intestinal mucosal immunity and enhances the protection of piglets against enterotoxigenic Escherichia coli K88 challenge. Gut Microbes. 2021;13(1): 1956281. https://doi.org/10.1080/19490976.2021.1956281.

33. Schoultz I, Keita AV. The intestinal barrier and current techniques for the assessment of gut permeabili. Cells-Basel. 2020;9(8):1909. https://doi.org/1 0.3390/cells9081909.

34. Murray MJ, Barbose JJ, Cobb CF. Serum D (-)-lactate levels as a predictor of acute intestinal ischemia in a rat model. J Surg Res. 1993:54(5):507-9. https://doi.org/10.1006/jsre.1993.1078.

35. Wu LH, Chen MH, Cai JY, Yuan Y, Wu LQ, Zhou HM, et al. The correlation between intestinal mucosal lesions and hepatic dysfunction in patients without chronic liver disease. Medicine. 2020;99(7):e18837. https://doi.org/1 0.1097/MD.0000000000018837.

36. Suryawan A, Davis TA. Amino acid-and insulin-induced activation of mTORC1 in neonatal piglet skeletal muscle involves Sestrin2-GATOR2, rag a/ C-mTOR, and RHEB-mTOR complex formation. J Nutr. 2018;148(6):825-33. https://doi.org/10.1093/jn/nxy044

37. Chassaing B, Srinivasan G, Delgado MA, Young AN, Gewirtz AT, Vijay-Kumar M. Fecal lipocalin 2, a sensitive and broadly dynamic non-invasive biomarker for intestinal inflammation. Plos One. 2012;7(9):e44328. https:// doi.org/10.1371/journal.pone.0044328.

38. Johansson MEV, Phillipson M, Petersson J, Velcich A, Holm L, Hansson GC. The inner of the two Muc2 mucin-dependent mucus layers in colon is devoid of bacteria. Proc Natl Acad Sci USA. 2008;105(39):15064-9. https:// doi.org/10.1073/pnas.0803124105.

39. He XJ, Lin YC, Lian S, Sun DB, Guo DH, Wang JF, et al. Selenium deficiency in chickens induces intestinal mucosal injury by affecting the mucosa morphology, SIgA secretion, and GSH-Px activity. Biol Trace Elem Res. 2020; 197(2):660-6. https://doi.org/10.1007/s12011-019-02017-6.

40. Yin J, Wu MM, Xiao H, Ren WK, Duan JL, Yang G, et al. Development of an antioxidant system after early weaning in piglets. J Anim Sci. 2014;92(2): 612-9. https://doi.org/10.2527/jas.2013-6986.

41. de Groot N, Fariñas F, Cabrera-Gómez C, Pallares F, Ramis G. Weaning causes a prolonged but transient change in immune gene expression in the intestine of piglets. J Anim Sci. 2021;99(4):skab065. https://doi.org/10.1 093/jas/skab065.

42. Braga PC, Dal Sasso M, Culici M, Galastri L, Marceca MT, Guffanti EE. Antioxidant potential of thymol determined by chemiluminescence inhibition in human neutrophils and cell-free systems. Pharmacology. 2006; 76(2):61-8. https://doi.org/10.1159/000089719.

43. Boudry $\mathrm{G}$, Perrier $C$. Thyme and cinnamon extracts induce anion secretion in piglet small intestine via cholinergic pathways. J Physiol Pharmacol. 2008; 59(3):543-52. 
44. Kulisic T, Radonic A, Katalinic V, Milos M. Use of different methods for testing antioxidative activity of oregano essential oil. Food Chem. 2004; 85(4):633-40. https://doi.org/10.1016/j.foodchem.2003.07.024.

45. Prieto JM, lacopini $\mathrm{P}$, Cioni $\mathrm{P}$, Chericoni $\mathrm{S}$. In vitro activity of the essential oils of Origanum vulgare, Satureja montana and their main constituents in peroxynitrite-induced oxidative processes. Food Chem. 2007;104(3):889-95. https://doi.org/10.1016/j.foodchem.2006.10.064

46. Zou Y, Hu XM, Zhang T, Wei HK, Zhou YF, Zhou ZX, et al. Effects of dietary oregano essential oil and vitamin $E$ supplementation on meat quality, stress response and intestinal morphology in pigs following transport stress. J Vet Med Sci. 2017;79(2):328-35. https://doi.org/10.1292/jvms.16-0576.

47. Tan CQ, Wei HK, Sun HQ, Ao JT, Long G, Jiang SW, et al. Effects of dietary supplementation of oregano essential oil to sows on oxidative stress status, lactation feed intake of sows, and piglet performance. Biomed Res Int. 2015; 2015:525218. https://doi.org/10.1155/2015/525218.

48. Liu Q, Duan RJ, Zhou YF, Wei HK, Peng J, Li JL. Supplementing oregano essential oil to boar diet with strengthened fish oil: Effects on semen antioxidant status and semen quality parameters. Andrologia. 2017;49(10): e12764. https://doi.org/10.1111/and.12764.

49. Neis EPJG, Dejong CHC, Rensen SS. The role of microbial amino acid metabolism in host metabolism. Nutrients. 2015;7(4):2930-46. https://doi. org/10.3390/nu7042930.

Ready to submit your research? Choose BMC and benefit from:

- fast, convenient online submission

- thorough peer review by experienced researchers in your field

- rapid publication on acceptance

- support for research data, including large and complex data types

- gold Open Access which fosters wider collaboration and increased citations

- maximum visibility for your research: over $100 \mathrm{M}$ website views per year

At $\mathrm{BMC}$, research is always in progress.

Learn more biomedcentral.com/submissions 